\title{
Risk Management In Developing Countries: Evidence From Multinational And Country Financial Risk Analysis
}

Gbolahan Osho, (Email: oshos@uhd.edu), University of Houston-Downtown Johnston Osagie, (Email: johnston.osagie@famu.edu), Florida A\&M University Michael O. Adams, (Email: Adams_MO@tsu.edu), Texas Southern University

\begin{abstract}
Much better access to international financial markets has granted many benefits to developing countries, but at the same time this approach has also exposed them to the unpredictable changes of these markets. However, the amount that can be hedged is limited because the other parties are usually given a ceiling to the total debt that they can get into with another country. Unlike borrowers, developing countries have limited possibilities of exploiting market niches to develop their investor base. The objective of this research paper is to look at different countries such as Russia and Mexico, and also realize how economic, political, and social risks account for these developing countries foreign and public debts; and how the management of these risks are necessary to combat the overall exposures these countries come across. With a fiscal view the primary cause of monetary growth in developing economies is usually found in large financial imbalances. The effect of inflation itself on the actual value of these countries financial deficits indicates the link between fiscal deficits, money growth, and inflation.
\end{abstract}

\section{INTRODUCTION}

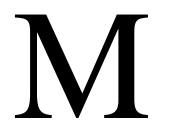

uch better access to international financial markets has granted many benefits to developing countries, but at the same time this approach has also exposed them to the unpredictable changes of these markets. The sizable external foreign currency debt of many developing countries makes them vulnerable to changes in international exchange rates, interest rates, and currency attacks. Cautious macroeconomic policies have at times been confused by the fiscal consequences of losses associated with these aspects. As the international outgrowth markets have grown with lack of clearness, the chances of hedging the risks that come with borrowing in foreign currencies has expanded a great deal. Borrowers can act on opportunities to exploit market holes, and develop their investor base without bringing about the exchange rate risk. They can also use the interest rate swap market to manage the fully developed structure of their external debt.

However, the amount that can be hedged is limited because the other parties are usually given a ceiling to the total debt that they can get into with another country. Unlike borrowers, developing countries have limited possibilities of exploiting market niches to develop their investor base. The objective of this research paper is to look at different countries such as Russia and Mexico, and also realize how economic, political, and social risks account for these developing countries foreign and public debts; and how the management of these risks are necessary to combat the overall exposures these countries come across.

\section{LITERATURE REVIEW}

Sensible macroeconomic policies at times have been compromised by the consequences of losses associated with swings in international exchange rates. The most recent of such policies is the one set out by Russia. Russia had defaulted on domestic debt, devalued the rubble, and froze the payments of earlier Soviet-era commercial debt. The United States and a few European banks lost some \$10 billion to debt default alone, and swore to never go near Russia 
again. Yet due to a change in macroeconomic policies, Russia was able to have some of their defaulted debts forgiven (Belton 2000). Now those banks that vowed never to do business with Russia, now praise the command of the country's return to international bond markets, in the form of a huge issue of restructured commercial debt. These financial critics are hoping for an unbelievable economic rebound. The main economic and financial initiative that had investors encouraged is that Russia had the best performing fixed income market in the years 1999 and 2000 (J.P. Morgan 2000). Other areas of policy changes involved the devaluation of the rubble at a time when oil prices surged. Russia also restructured $\$ 32$ billion in soviet-era commercial debt (figure 1). Banks wrote off $\$ 10.6$ billion and Russia issued a $\$ 18.2$ billion 30-year issue, and a $\$ 10.6$ billion 10-year issue for the balance (Belton 2000). Other defaulted nations looked on and found themselves in not so fortunate of a position.

\section{Figure1: The Distribution of Country Equity Returns}

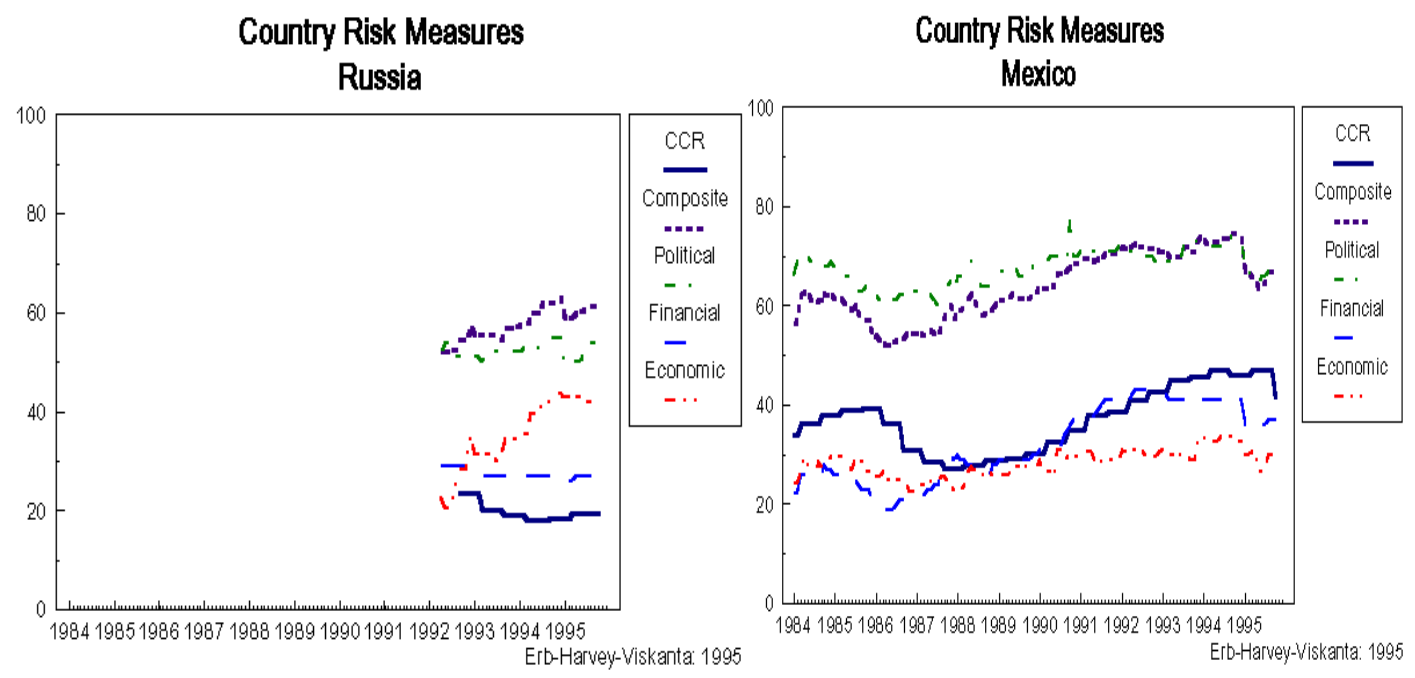

Exposure of developing countries to currency risk can be broadly measured by the amount of external public debt they have incurred. In 1996, the outstanding stock of sovereign debt issued or guaranteed by developing countries was $\$ 1.5$ trillion, or 300 percent of their foreign currency reserves. About one-half of their external debt was open to foreign interest rate risk. During the past two decades, a great deal of emerging markets in developing countries has been hurt by adverse movements in exchange rates and international interest rates. In the early 1980's, the debt servicing loads of some countries in Africa, southeast Asia, and Latin America, were affected a great deal. Coming from the dollars' appreciation, a worldwide increase in interest rates, and a decline in commodity prices occurred. Several Asian countries saw significant increases in their debt burdens in the early 1990's; this was due to their unheeded exposures to Japanese yen. A third of the increase in the dollar value of Indonesia's external debt between 1993 and 1995 was due to cross currency movements, in particular the steep appreciation of the yen. At the time, 37 percent of Indonesia's external debt was denominated in yen, while around 90 percent of its export revenues were denominated in dollars (Agnor 1995).

A country's vulnerability to external shocks contributes to their total amount of debt, which is shown in the case of Mexico. Mexico's public debt was rather low by the Organization for Economic Cooperation and Development (O.E.C.D.1995) standards, 51 percent of GDP, compared with an average of 71 percent for the O.E.C.D. countries. The Mexican crisis shows the difficulty and cost of refinancing a real volume of foreign currency debt that was to mature in turbulent foreign exchange markets. Mexico's economy was susceptible to a financial crisis because their foreign exchange reserves totaled $\$ 6.3$ billion at the end of 1994 , and their short term securities indexed to the dollar were worth $\$ 29$ billion, and due to mature in 1995 (O.E.C.D. 1995). The O.E.C.D. believes that the risks associated with a large net currency exposure, along with the existence of deep and liquid domestic capital markets, are the main reasons that the governments of a great deal of the industrial countries have limited their giving out of 
foreign currency debt. These governments have established legal clauses that are supported by the lawmakers of their countries.

Large advanced economies such as Germany, Japan, and the United States do not issue foreign currency debt, while France and the United Kingdom issue a small amount in ECU's. Foreign currency debt represents around 3 percent of total public debt in Canada, and their budget deficit is all funded in domestic currency. Small advanced economies such as, Belgium, Denmark, and New Zealand have stopped issuing foreign currency debt except to replenish their foreign currency reserves. In Ireland, gross foreign currency borrowing is limited to the level of maturing foreign currency debt. Spain and Sweden issue foreign currency debt, but they hedge their currency risk through swap options. However, in developing countries governments need to access international debt markets to balance out their shortage of local savings, lengthen the maturity of their debt, diversify their interest rate risk exposure, accumulate foreign exchange reserves, or come up with a way for domestic private entities to issue abroad. The foreign currency could be switched to domestic currency, or to a currency that is closely related to the domestic currency in which liquid optional markets exist. This would prevent borrowing strategies aimed at reducing interest rates, along with softening internal budget constraints (Agnor 1995).

It seems that these countries are at financial risks all the time despite the attractive opportunities that are available. They just cannot seem to meet their financial obligations, but they continue to take lengthy financial risks in the form of loans from the World Bank, and the international monetary fund. It seems that these countries do not fully know the risks involved, and they are stuck with hard and discouraging repayment guidelines. Many underdeveloped countries that have borrowed heavily in foreign currencies in the past are now faced with important policy changes. These changes include how to manage their currencies, interest rates, and their maturity risks associated with their debts. In order for these countries to implement policies that will aid them in fulfilling their obligations to external creditors, they require management by non-political sections of their communities. This is not always so easy for administrators whose goals are to earn the highest returns from their resources, and please their domestic demands (O.E.C.D. 1995).

Management of the risks that come along with external exposures requires technical expertise, sophisticated information technology, and controlled internal management procedures that contain steady enforcement of trading and exposure limits. These requirements are hard to follow even in the best of circumstances, therefore making it very difficult in developing countries. Some emerging markets have found it hard to bring in qualified staff, build sufficient information and control systems, and develop the administrative controls that are needed to manage overall exposures because they often begin without the necessary financial tools to support these initiatives (Dubash 2000). Management should be protected from political interference to help to secure transparency and accountability. The debt management of developing countries should be entrusted to portfolio managers who have knowledge and experience in risk management techniques, and these managers should be measured according to a set of criteria set forth by the ministry of finance. Lastly, enough resources need to be designated to hiring high quality staff, and getting sophisticated support systems (O.E.C.D. 1995).

The extent of a country's outside position on its creditworthiness is measured by the extent of its existing obligations. The scale of a country's outside payment obligation is determined by the ratio of its external debt to GDP. Credit rating agencies tend to rate high debt countries differently than low debt countries. The country's ability to make good on their external obligations is assumed to be shown in the growth rate of its exports, it's current account position, the ratio of its non-gold international reserves to imports, and it's real exchange rate. In most instances, the developing countries have low ratings in almost all of these areas. Because they are lacking in these points, it is important for them to effectively manage the other aspects of the ratings. These other areas are the internal economic, political, and social factors that also control their credit ratings (Table 1).

For countries that have been going through a high rate of inflation, a sharp drop in their inflation rate will improve their credit rating a great deal. More often than not, the strategy of these underdeveloped countries is to devise policies to feed, clothe, and house themselves at the cost of the lenders or investors, instead of trying to pursue economic policies such as those that Russia was able to implement. These governments main goal should be to 
improve their country's current account balance, along with implementing a program for the revival of growth through economic recovery systems (Dubash 2000).

Table 1: Market Weights in the International Finance Multinational Corporation IFMC Indices

\begin{tabular}{|c|c|c|c|c|c|c|}
\hline & $\begin{array}{l}\text { IFMC } \\
\text { Global } \\
\text { Indices }\end{array}$ & & & $\begin{array}{l}\text { MC } \\
\text { vestable } \\
\text { dices }\end{array}$ & & \\
\hline Market & $\begin{array}{l}\text { No. of } \\
\text { Stocks }\end{array}$ & $\begin{array}{c}\text { Market } \\
\text { Capitalization } \\
\text { (US\$ Mil) }\end{array}$ & $\begin{array}{c}\text { Weight } \\
\text { in IFC } \\
\text { Composite } \\
\end{array}$ & $\begin{array}{l}\text { No. of } \\
\text { Stocks }\end{array}$ & $\begin{array}{c}\text { Market } \\
\text { Capitalization } \\
\text { (US\$ Mil) }\end{array}$ & $\begin{array}{c}\text { Weight } \\
\text { in IFC } \\
\text { Composite } \\
\end{array}$ \\
\hline Argentina & 35 & 22307.8 & 2 & 31 & 22161.1 & 3.5 \\
\hline Brazil & 86 & 93939.6 & 8.5 & 68 & 63813.7 & 10.2 \\
\hline Mexico & 81 & 65162.4 & 5.9 & 65 & 58686.5 & 9.3 \\
\hline Peru & 36 & 7421.7 & 0.7 & 20 & 6910 & 1.1 \\
\hline Venezuela & 16 & 2652.3 & 0.2 & 5 & 1930.8 & 0.3 \\
\hline China & 171 & 29494.8 & 2.7 & 23 & 3005.5 & 0.5 \\
\hline Korea & 151 & 125037.1 & 11.2 & 145 & 17314.7 & 2.8 \\
\hline Philippines & 46 & 39729.2 & 3.6 & 35 & 19314.9 & 3.1 \\
\hline India & 131 & 71141.3 & 6.4 & 76 & 14792.2 & 2.4 \\
\hline Indonesia & 45 & 54570.7 & 4.9 & 44 & 27724.6 & 4.4 \\
\hline Malaysia & 123 & 162134.5 & 14.6 & 123 & 135326 & 21.5 \\
\hline Pakistan & 68 & 6646.6 & 0.6 & 25 & 4951 & 0.8 \\
\hline Czech Republic & 69 & 12346.3 & 1.1 & 5 & 5206.7 & 0.8 \\
\hline Jordan & 51 & 3276.3 & 0.3 & 8 & 1107.4 & 0.2 \\
\hline Portugal & 30 & 11404.5 & 1 & 26 & 9012 & 1.4 \\
\hline South Africa & 63 & 105981.4 & 9.5 & 63 & 105981.4 & 16.9 \\
\hline \multicolumn{7}{|l|}{ Regions } \\
\hline Composite & 1682 & 1112233 & 100 & 1116 & 628429.1 & 100 \\
\hline Latin America & 329 & 237564 & 21.4 & 247 & 197855.5 & 31.5 \\
\hline Asia & 935 & 699579.5 & 62.9 & 631 & 271211.4 & 43.2 \\
\hline EMEA & 394 & 175089.1 & 15.7 & 238 & 159362.2 & 25.4 \\
\hline
\end{tabular}

Sources: Analyst/Contact: Campbell R. Harvey

\section{RESULT ANALYSIS}

The large foreign currency exposure of emerging markets can be explained by a number of factors; including low domestic savings rates, the lack of domestic borrowing instruments, and the high proportion of official financing which tends to be denominated in the donor countries currencies. Governments issue debt in foreign currencies, to show that they are committed to a policy of stable exchange rates or prices. At the same time, policy makers may show a commitment to stable prices by issuing inflation-indexed bonds. These bonds generally serve the interest of the country, and sometimes the returns are not promising to the foreign investors, they tend to serve the interest of the administration and not the population of the country. 


\section{Figure 2: International Country Returns Moments vs. Risk Attributes}
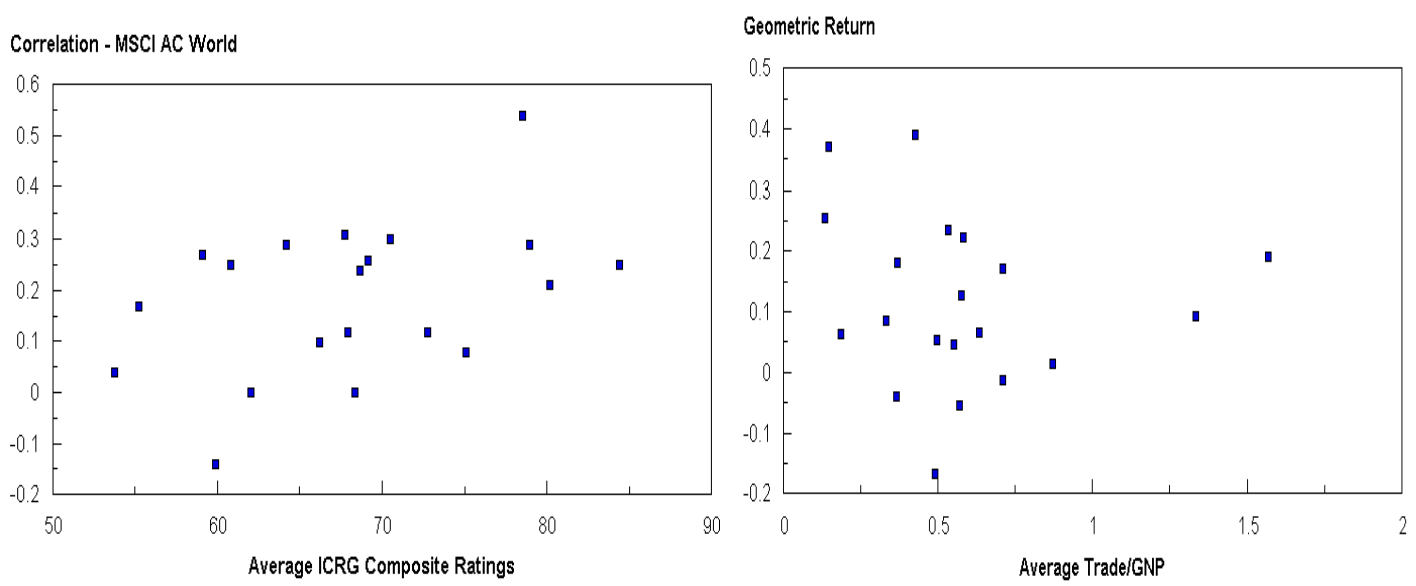

More recently emerging markets have regained access to international debt markets, and the choice of currencies and maturity structures, are often driven by the desire to gather the fiscal gains of borrowing in countries with low coupon rates. The leaders of these developing countries often underestimate the risk involved with unstable foreign currency borrowing for various reasons. First, the ability of governments to generate foreign currency revenues to repay their obligations is limited, especially if the country lacks natural resources. Making government assets consisting mainly of the discounted value of future taxes in local currency.

Second, it is not likely that the costs in terms of output, welfare, and reputation that a country could come across in the event of a opposing external shock, is taken into account in an emerging markets external borrowing strategies. Although the likelihood of crises is small, except in the case of natural disasters, the potential disorder to an economy is great, as seen in many unstable third world regimes. A foreign exchange exposure boosts the economic impact of external shocks, and limits the financial policy options available during a financial crisis. For example, a country with a large net foreign currency obligation would have a hard time pursuing an aggressive monetary policy in the mist of a financial crisis. This is because it might cause a sharp decline in the domestic currency, which ultimately limits investment abroad, as well as at home.

A depreciation in the currency could worsen the country's debt and risk profile, and harden the financial crisis. In the event of a real exchange rate shock, a government will be faced with the spike of its external debt servicing costs, and a drop in the foreign currency values of its revenues.

Along with potential capital losses, a government may incur on its debt portfolio, being able to enter international markets to refinance its growing debt is likely to be hindered. Taking the previous mentioned issues into consideration will be advantageous for the lender and the borrower as long as they understand their obligations, since it is possible that both could end up losing in the end (Table 2).

\section{SUMMARY AND CONCLUSIONS}

This paper examines the short run links between money growth, exchange rate depreciation, nominal wage growth, repeated movements in output, and inflation in middle income developing countries such as Russia, Mexico, Belgium, and Denmark, to mention a few (Table 3). With a fiscal view the primary cause of monetary growth in developing economies is usually found in large financial imbalances. In many of these countries, inefficient ways of collecting revenues and limited development of financial markets, make these countries rely on borrowing money to finance their financial deficits. The effect of inflation itself on the actual value of these countries financial deficits, show to support the link between fiscal deficits, money growth, and inflation. On the other hand, the balance of payment view showed the causes of exchange rate movements on domestic and foreign prices. 
Table 2: Comparison of International Finance Multinational Corporation IFMC and Morgan Stanley. Capital International MSCI Emerging Market Global Indices

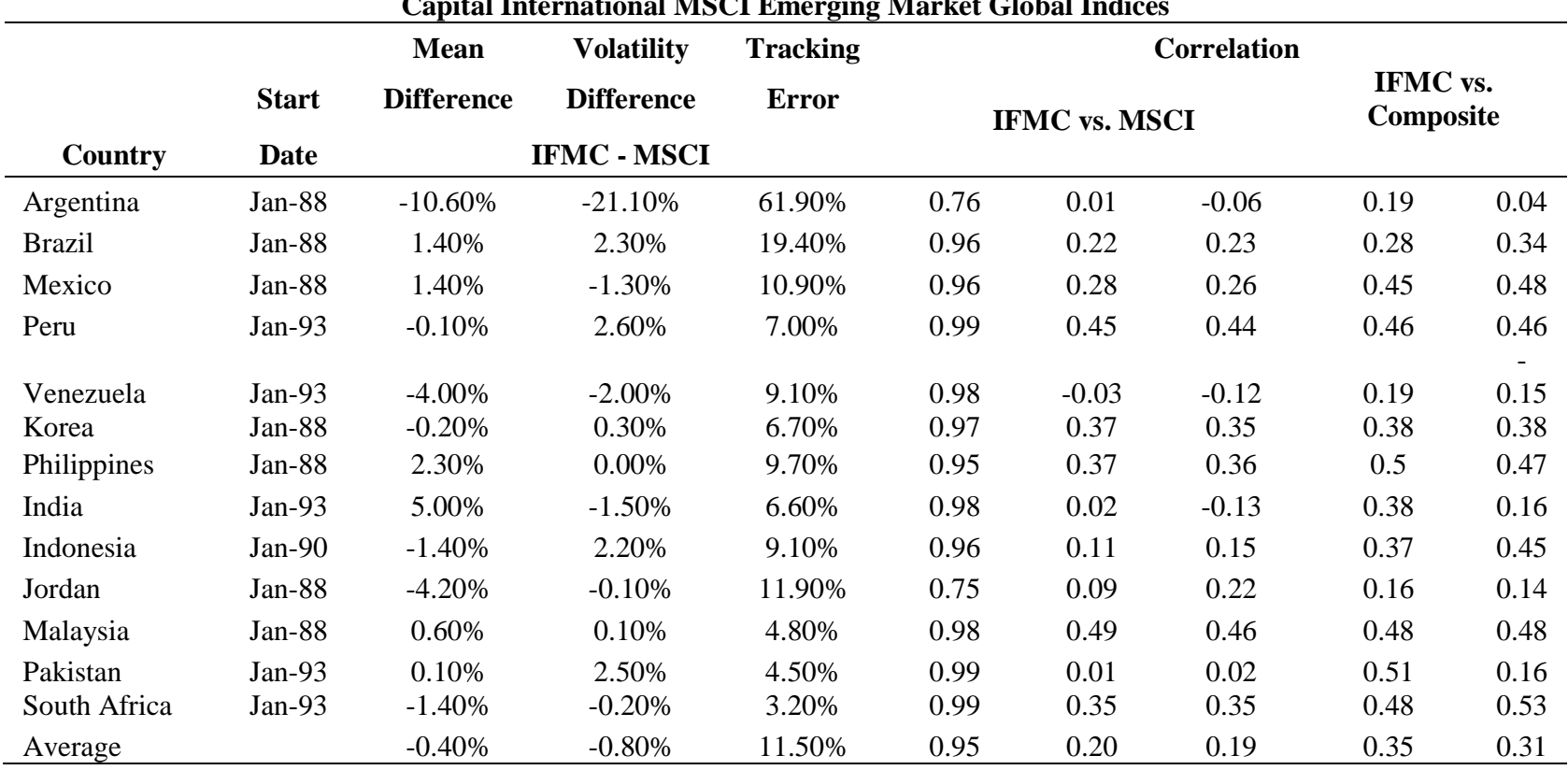

Source: IFC Global Indices, MSCI EM Indices Monthly returns in US Dollars.

Figure 3: Semi Annual Cross-sectional Regressions Country Index Returns on lagged Risk Level Institutional Investor CCR

Slope Coefficient

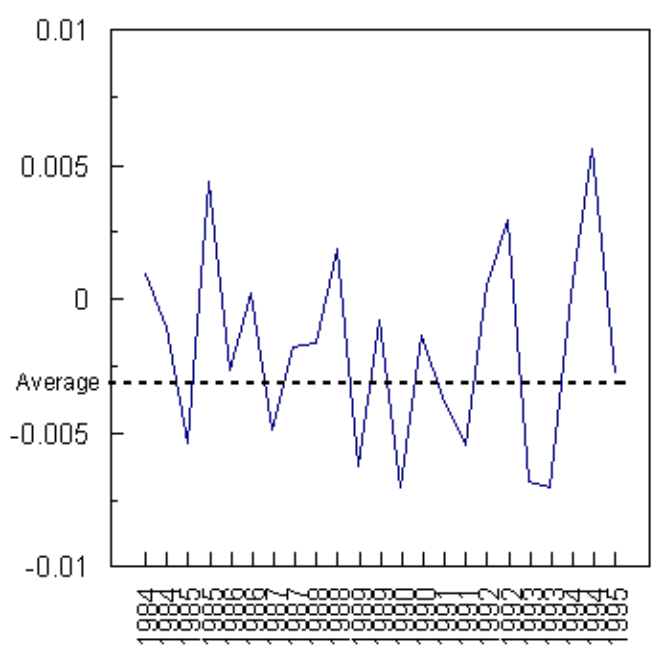

R-Squared

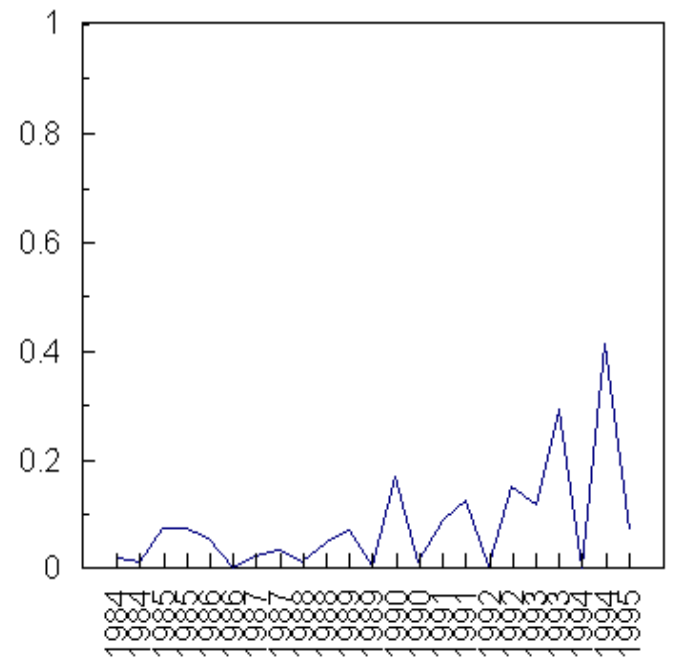

Movements like exchange rate depreciations, are usually the results of harmful developments in the balance of payments. Such developments may reflect on the risk management of the assets and liabilities of these developing countries, and their unnecessary government spending, which causes them not to meet their financial obligations (Figure 3). 
ICRGC: Political Risk Services: International Country Risk Guide - Composite

ICRGP: Political Risk Services: International Country Risk Guide - Political

ICRGF: Political Risk Services: International Country Risk Guide - Financial

ICRGE : Political Risk Services: International Country Risk Guide - Economic

IICCR: Institutional Investor Country Credit Ratings

EMCRR: Euromoney Country Risk Ratings

INFLATE: Annual Consumer Inflation: IFS Database

TRDGDP: Trade Openness (Exports + Imports)/GDP

POPGR: Annual Growth in Total Population - UN Data

AAGEGR: Annual Growth in Average Age of Population - UN Data

AVEAGE: Average Age of Population - UN Data

MKTCAP: IFC Global Market Capitalization (Millions of US\$)

P/E: IFC Global Price/Earnings Ratio

P/B: IFC Global Price/Book Ratio

P/D: IFC Global Price/Dividend Ratio

Table 3: Country Risk Level Portfolio Strategy with Country Attributes

\begin{tabular}{|c|c|c|c|c|c|c|c|c|c|c|c|}
\hline Country & IICCR & EMCRR & INFLATE & TRDGDP & POPGR & AAGEGR & AVEAGE & MKTCAP & $\mathrm{P} / \mathrm{E}$ & $\mathrm{P} / \mathrm{B}$ & $\mathrm{P} / \mathrm{D}$ \\
\hline Argentina & 38.4 & 57.2 & $0.70 \%$ & $12.80 \%$ & $1.20 \%$ & $0.30 \%$ & 30.9 & 22308 & 16.7 & 1.4 & 29.2 \\
\hline Brazil & 35.8 & 55.4 & $29.20 \%$ & $13.60 \%$ & $1.70 \%$ & $0.80 \%$ & 27.1 & 93940 & 40.3 & 0.5 & 28.9 \\
\hline Chile & 59.2 & 79.8 & $7.60 \%$ & $42.10 \%$ & $1.60 \%$ & $0.60 \%$ & 29 & 39421 & 15.9 & 1.9 & 26.1 \\
\hline China & 56.4 & 70.8 & & & $1.00 \%$ & $0.90 \%$ & 29.6 & 29495 & 31.8 & 2 & 37.6 \\
\hline India & 45.8 & 66.7 & $9.70 \%$ & $17.20 \%$ & $1.90 \%$ & $0.50 \%$ & 26 & 71141 & 14.3 & 2.3 & 65.8 \\
\hline Indonesia & 51.8 & 73.2 & $10.50 \%$ & $43.90 \%$ & $1.50 \%$ & $0.80 \%$ & 26.2 & 54571 & 26.6 & 3.5 & 112.4 \\
\hline Jordan & 30.5 & 54.3 & $7.00 \%$ & $130.10 \%$ & $4.60 \%$ & $0.30 \%$ & 21.4 & 3276 & 15.6 & 1.7 & 50 \\
\hline Malaysia & 68.4 & 84.5 & $3.30 \%$ & $166.40 \%$ & $2.30 \%$ & $0.60 \%$ & 24.8 & 162134 & 28.4 & 3.7 & 83.3 \\
\hline Pakistan & 29.5 & 50.7 & $9.80 \%$ & $35.40 \%$ & $2.80 \%$ & $0.30 \%$ & 21.9 & 6647 & 16.4 & 2.1 & 45.7 \\
\hline Peru & 27.2 & 47.5 & $11.60 \%$ & $20.20 \%$ & & & & 7422 & 13.8 & 2.7 & 90.1 \\
\hline Philippines & 38.1 & 63.5 & $12.30 \%$ & $54.30 \%$ & $2.10 \%$ & $0.60 \%$ & 24 & 39729 & 21.2 & 3.8 & 153.8 \\
\hline South Africa & 46.3 & 64.9 & $6.80 \%$ & $38.50 \%$ & $2.20 \%$ & $0.20 \%$ & 25 & 105981 & 19.2 & 2.7 & 49 \\
\hline South & 72 & 85 & $4.50 \%$ & $53.70 \%$ & $1.00 \%$ & $1.00 \%$ & 30.5 & 125037 & 21 & 1.3 & 54.3 \\
\hline Sri Lanka & 32.5 & 50.6 & $11.80 \%$ & $80.70 \%$ & $1.30 \%$ & $0.90 \%$ & 28.2 & 1315 & 8.9 & 1.5 & 39.8 \\
\hline Taiwan & 78.9 & 91.5 & $3.00 \%$ & $86.70 \%$ & & & & 114475 & 21.6 & 2.8 & 85.5 \\
\hline \multirow[t]{3}{*}{ Venezuela } & 30.1 & 44.7 & $78.10 \%$ & $40.10 \%$ & $2.20 \%$ & $0.80 \%$ & 25.1 & 2652 & 16.3 & 2.6 & 63.3 \\
\hline & \multicolumn{11}{|c|}{ Rank Correlations } \\
\hline & IICCR & EMCRR & INFLATE & TRDGDP & POPGR & AAGEGR & AVEAGE & MKTCAP & $\mathrm{P} / \mathrm{E}$ & $\mathrm{P} / \mathrm{B}$ & $\mathrm{P} / \mathrm{D}$ \\
\hline IICCR & 1 & 0.97 & -0.61 & 0.39 & -0.58 & 0.54 & 0.53 & 0.66 & 0.36 & -0.02 & 0.13 \\
\hline EMCRR & & 1 & -0.65 & 0.38 & -0.54 & 0.44 & 0.48 & 0.71 & 0.45 & 0.06 & 0.21 \\
\hline INFLATE & & & 1 & -0.31 & 0.24 & -0.1 & -0.27 & -0.5 & -0.28 & 0.02 & 0.06 \\
\hline TRDGDP & & & & 1 & 0.02 & 0.18 & -0.11 & -0.06 & -0.02 & 0.06 & -0.01 \\
\hline POPGR & & & & & 1 & -0.47 & -0.95 & -0.09 & -0.05 & 0.35 & -0.07 \\
\hline AAGEGR & & & & & & 1 & 0.39 & 0.36 & 0.26 & -0.12 & 0.11 \\
\hline AVEAGE & & & & & & & 1 & 0.07 & 0.02 & -0.36 & -0.09 \\
\hline MKTCAP & & & & & & & & 1 & 0.68 & 0.26 & 0.27 \\
\hline $\mathrm{P} / \mathrm{E}$ & & & & & & & & & 1 & 0.16 & 0.37 \\
\hline $\mathrm{P} / \mathrm{B}$ & & & & & & & & & & 1 & 0.27 \\
\hline $\mathrm{P} / \mathrm{D}$ & & & & & & & & & & & 1 \\
\hline
\end{tabular}

\section{REFERENCES}

1. Agnor, Pierre, and Hoffmeister, (1995). Money, Wages, and Inflation in Developing Countries. I.M.F.

Report.

2. Belton, Catherine (10/2000). Russia-all is Forgiven._Business Week, October $9^{\text {th }} .2000$.

3. Dubash, Navriz Dr. (2000). The Right Conditions, The World Bank Structural Adjustment Program. World Bank Report, March 2000.

4. $\quad$ J.P. Morgan (2000). Emerging Benchmark Index. September 2000.

5. O.E.C.D. Reports (1995). The Use of Economic Instruments for Financial Management in Developing Countries. 